Papers and Proceedings of the Royal Society of Tasmania, Vo1.109, 1975.

(ms. received 14.2 .1974 )

\title{
NON-MARINE ARTHROPODA OF THE TASMANIAN TRIASSIC
}

by Paul Tasch

Dept. of Geology, Wichita State University, Wichita, Kansas

communicated by M.R. Banks

(with one text-figure and one plate)

\section{ABSTRACT}

Conchostracan fossils are described for the first time from Triassic rocks in Tasmania. Taxa present include Cyzicus (Lioestheria) spp., Palaeolimmadia (Palaeolimadia) cf. wianamattensis, P. (Palaeolimadia) banksia n. sp., P. (Palaeolimadia) poatinis n. sp. other species of Palaeolimnadia and Palaeolimadopsis tasmanii n. sp. Two assemblages, one with Falaeolimadia alone, the other with Palaeolimnadia and Cyzious. The latter assemblage suggests correlation with the Blina Shale in Western Australia and with the Mangli Beds of India. The conchostracans lived in small, transitory bodies of water (Ed.).

\section{INTRODUCTION}

Two groups of conchostracan-bearing samples were available for this study, the University of Tasmania Collection (UT) and the Tasch Collection. The former includes samples from the Ross Sandstone at Poatina, the presumably overlying Knocklofty Sandstone and Shale at Tinderbox Bay $(526.65 \mathrm{~km} \mathrm{E} .5232 .5 \mathrm{~km} \mathrm{~N}$.), Knock1ofty $(524.7 \mathrm{~km} \mathrm{E}$. $5250.225 \mathrm{~km} \mathrm{~N}$.) and Cascades (524.45 km E. $5250.08 \mathrm{~km} \mathrm{~N}$.) as well as the still younger bed (according to Mckellar $1957 \mathrm{cit}$. Spry and Banks 1962, p. 226) the Brady Formation at Poatina. The second group comprises the Tasch Collection (TCT) (collected in company with $\mathrm{Mr}$. M.R. Banks) from the Knocklofty Formation of the Knocklofty area, Old Beach (east side of River Derwent, $523.75 \mathrm{~km} \mathrm{E.} 5262.5 \mathrm{~km} \mathrm{N.)} \mathrm{and}$ the beach at Conningham (523.25 km E. $5230.25 \mathrm{~km} \mathrm{~N}$.) south of Hobart, as well as two quarries in Hobart (fig. 1).

\section{THE FOSSIL BIOTA}

Components

The biota represented in the specimens studied is very sparse in non-conchostracan elements. It consists of a single carbonized half of a malacostracan shield (UT 93983) (P1. 1, fig. 10); carbonized plant debris (slab 54732 on which conchostracan species UT 8 occurs, and slab 54664 on which no conchostracans occur but which contains on several levels, carbonized plant debris); a possible fragment of an insect wing (TCT, Conningham) and on one impression of a conchostracan valve possible epibionts (worm borings) and a probable beaded faecal string (TCT 105, P1. 1, fig. 9).

Essentially, the conchostracan fossils of the University of Tasmania collection constitute a Palaeolimadia fauna in the Ross Sandstone and a Palaeolimnadia-Cyzicus fauna in the possibly younger Knocklofty Formation. The conchostracans of the Tasch Collection from the Knocklofty are characterized by dominance of Palaeolimadia at all localities, but some cyziciids are also present. Since the University and Tasch Collections from the Knocklofty came from different localities (fig. 1) it is apparent that the same faunal elements (with rare exception) spread throughout the area during Knocklofty time. 


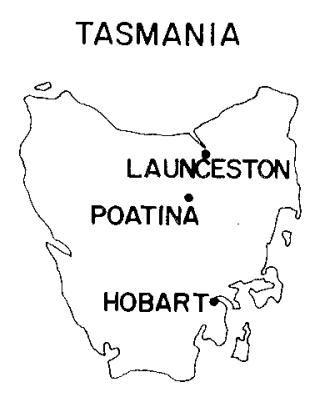

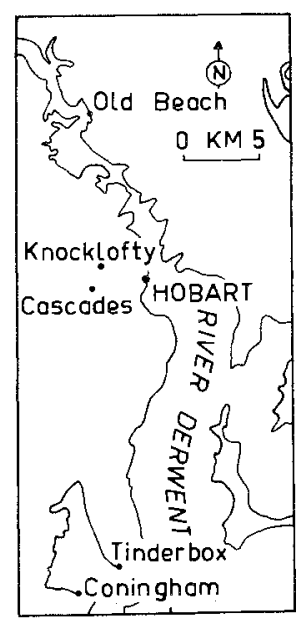

FIG. 1. - Conchostracan Collection Sites.

Preservation In all

instances fossil preservation is extremely poor. Many specimens are known only as external valve impressions.

Coquinoid ass emblages lead to obscuring of many valves by overlapping ones. Erosion has removed a good deal of data from numerous remnant valves. Fortunately some telltale features are frequently preserved as for example the comparatively large umbo of the palaeolimnadiid conchostracans. Occasionally as in TCT 105 (P1. 1, fig. 9) evidence of apparent epibionts has not

been destroyed totally. Carbonized fossils are restricted to thin films of conchostracan valves (UT 12F), fragmentary plants and one malacostracan shield.

\section{Lithologies}

Shales and sandstone are dominant. Shales include: laminated gray (Knocklofty) and hard, tan (Poatina) varieties. The sandstones are either conglomeratic, buff or tan (Cascades, Conningham, Knocklofty) or similar sandstones contain light gray conchostracan-bearing shale chips (Knocklofty) or clay pebbles (Old Beach).

\section{PALAEOECOLOGY}

\section{Population Density}

Some idea of population density can be obtained by determination of number of valves or valve impressions per given area of a slab. In the Knocklofty Formation at Tinderbox, a slab area of $43 \mathrm{~mm} \times 16 \mathrm{~mm}$ contained 21 valves; at Knocklofty, a slab area of $20 \mathrm{~mm} \times 14 \mathrm{~mm}$ contained 21 valves, while in the Ross Formation at Poatina, a slab area of $70 \mathrm{~mm} \times 52 \mathrm{~mm}$ contained 40 valves. These valves are in close proximity or in coquinoid assemblages on the bedding plane. Obviously since each conchostracan had two valves the actual population count represented by these figures was at least one half the cited number.

There was a greater density per unit area in the Knocklofty area than at Tinderbox, and at both sites than at Poatina during deposition of Ross Sandstone. Such densitiescoquinoid assemblages in very small areas, suggest mass death in mini-basins that were probably relicts of evaporating larger basins. 
Paul Tasch

\section{Restricted Biota}

Exclusive of the vertebrates-fish, labyrinthodont amphibians, reptile

(Cosgriff 1974), the conchostracans, plants and possible epibionts and insect constitute a restricted community. However, this is not unusual for such nonmarine facies.

\section{Number of Generations}

To determine number of conchostracan generations one must be able to follow successive occurrences of valves along the vertical or jagged face of a slab. With one exception, the material on hand did not allow for this since fossil conchostracans were confined to single bedding planes. One slab (TCT, Knocklofty, slab 2) had a thickness of $3.15 \mathrm{~mm}$ and contained 13 successive generations.

Sedimentation Rate

From the same slab (slab 2) noted above, the average sedimentation rate was determined by dividing number of generations into slab thickness. The rate was $0.24 \pm$ $\mathrm{mm} / \mathrm{yr}$ for the Knocklofty site (at Knocklofty). This rate may be taken as probably the right magnitude although variations may be expected, however slight, from one site to another during the time represented by the deposits.

\section{Durations of Water Basins}

Living conchostracans cultured in the writer's laboratory and observed in the wild, generally endure for the lifespan of the given water body (pond, lake margin, river floodplain, hoofprint puddles) in which they live. That is, almost up to the time of complete evaporation of such water bodies, conchostracans continue to grow. As the water evaporates they are restricted to still smaller relicts. In old age (over 15 growth bands) there is a slow-down in growth. (The latter is accomodated in calculations by a minus 15 days corrections).

In the present conchostracan assemblage cyziciids with up to $19+$ growth bands (Knocklofty Formation at Knocklofty) denote a maximum endurance of any individual at the given site, of 57 days, which corrected as noted above, comes to 42 days. Palaeolimnadia (Palaeolimnadia) of the Ross Sandstone at Poatina had a maximum of 12 growth bands and endured 36 days, while another subgenus $P$. (Grandizimnadia) of the Knocklofty at Cascades and 01d Beach, had up to 17 growth bands representing 51 minus 15 days, or some 36 days.

From the cited figures it follows that one month to one- and one-half months was the maximum time of endurance for any of the conchostracan-bearing ponds or puddles of this study.

\section{CHANG ING COMMUNITY STRUCTURE}

In the Ross Sandstone only species of Palaeolimnadia subgenus Grandizimnadia occur. The possibly younger sequence, the Knocklofty Sandstone and Shale contains this same faunal element as well as a second subgenus, Palaeolimnadia and other biotic elements which may be new to the region during the time interval being discussed, Cyzicus (Lioestheria) - three species - and Palaeolimnadiopsis, as well as a malacostracan genus, possibly insects, epibionts, and plants. No arthropod fossils vere found in samples from the higher unit, the Brady Formation, al though estheriids have been reported from the Brady (Banks, p. 40 in Williams and Smith 1965).

\section{DISCUSSION}

Cosgriff (1974) referred to the Knocklofty-Blina horizon based on fossil amphibians (BIinascums etc.) from the Lower Triassic of Tasmania. He also noted that the named amphibian was most closely related to Brachyops of the Mangli beds of India, among others, and that the horizon "appears to be above the Lystrosaums zone". 


\title{
Triassic Non-Marine Arthropoda
}

Data on Knocklofty conchostracans lend support to the correlation with the Blina Shale. Study of the Blina Shale conchostracans from Canning Basin cores (by the author) show that the Blina and Knocklofty Formations share two genera and three subgenera of conchostracans: Palaeolimnadia (Palaeolimadia), Palaeolimnadia (Grandilimnadia), Cyzicus (Lioestheria). The Knocklofty shares one genus and subgenus with the Mangli Beds of India, recently studied by the writer and colleagues from the Geological Survey of India, namely Cyzicus (Lioestheria).

The Mangli Beds of India, some 91.5 metres above the GZossopteris beds, were placed near the base of the Upper Panchets (with reference to the Triassic section of the Raniganj Coal Basin) (Tasch et al.1973). Lystrosourus is abundant in the Upper Panchets but occurs sparsely in the Lower Panchets. Accordingly, if the Lystrosaums zone is taken to designate that portion of the section where that genus is abundant (Upper Panchets) then the Mangli Beds are below the Lystrosaurus zone. If the zone is taken to include sparse though abundant occurrences, then the Mangli Beds are stratigraphically in the Iystrosaumis zone. Either way Cosgriff's inference that "the Knocklofty-Blina horizon appears to be above the Lystrosoums zone" needs modification. (Cf. Tripathi and Satsangi 1963).

Another view is sponsored by the finding of a palaeolimnadid, some 36 metres above the Schizoneura-GLossopteris transition zone in the Lower Panchets (Raniganj Basin) (Data in Tasch et al. 1973). This paleolimnadid horizon is quite likely the equivalent of the palaeolimnadid bed of the Tasmanian Knocklofty Formation. That would place it well below the Mangli Beds in the basal Upper Panchets. Following this correlation the Brachyope of the Mangli Beds then occur stratigraphically higher (i.e. geologically younger) than the Knocklofty labyrinthodonts of Cosgriff.

\section{PALAEOLIMNADID CONCHOSTRACAN CORRELATIONS}

Presence of Triassic palaeolimnadid conchostracans in eastern Australia (Bowen and Sydney Basins) and Western Australia (Bonaparte Gulf and Canning Basins) as well as in the Ross Sandstone and Knocklofty Formation of Tasmania, and in the Lower Panchets (Raniganj Basin) of India indicates comparative proximity of West Australia to India. It al so shows dispersal between eastern Australia and Tasmania and between Western and eastern Australia during Triassic time.

Cosgriff (1974) noted that in addition to vertebrate fossil evidence, palynological evidence supports the close synchroneity of the Knocklofty and Blina Formations (the latter from the Canning Basin of Western Australia). This paper brings independent evidence of a third kind - nonmarine palaeolimnadid conchostracans, in support of this correlation.

The origin of the Tasmanian palaeolimnadids was probably in the eastern Australian Triassic basins. Palaeolimnadid eggs could have been dispersed from eastern to Western Australia by a series of freshwater "stepping stones". The proximity of India and Western Australia would then explain the Indian Raniganj Basin occurrence.

\author{
SYSTEMATIC PALAEONTOLOGY \\ Cyzicus Audouin, 1837 \\ Cyzicus (Lioestheria) sp. 1
}

Diagnosis: subovate valves; umbo situated closer to anterior side: hachure type markings on growth bands.

Material: Slab No. 54662 contains some 21 similar valves. Excepting the two valves noted below under "Measurements", all others are in close proximity. However, these are poorly preserved as carbonized films and eroded both over the centre of the valve and the umbonal region. Not figured. 
Paul Tasch

Measurements:

$\begin{array}{llccccc}\text { Specimen No. } & \text { Valve } & \begin{array}{c}\text { Length }(\mathrm{mm}) \\ (1)\end{array} & \begin{array}{c}\text { Height }(\mathrm{mm}) \\ (\mathrm{h})\end{array} & \mathrm{h} / 1 & \mathrm{a}^{*} & \mathrm{p}^{* *} \\ \text { UT 12 F, 1 } & \text { Right } & 2.70 & 2.10 & 0.77 & 15 & 25 \\ \text { UT 12 F, 2 } & \text { Left } & 2.70 & 1.95 & 0.72 & 15 & 15\end{array}$

*antero-dorsal angle, ** postero-dorsal angle.

Locality: Knocklofty Formation, Tinderbox Bay.

Cyzious (Lioestheria) sp. 2

(P1. 1, fig. 3)

Diagnosis: narrowly ovate; umbo, subterminal; dorsal margin straight; ornamentation punctate.

Material: A pair of valves are present; the upper being the left valve and obscuring most of the underlying right valve. Both valves are carbonized. Slab 54664, UT 11 . Measurements: Length $=4.05 \mathrm{~mm} ;$ height $=2.70 \mathrm{~mm} ; \mathrm{h} / 1=0.66$, antero-dorsal angle $=30^{\circ}$; postero-dorsal angle $=65^{\circ}$; ratio of length of valve $(1)$ to length of dorsal margin $(1 \mathrm{dm})=0.52$. Growth bands, $16+$ (eroded on umbonal sector).

Discussion: Distinguished from $C$. (Lio.) sp. 1 by overall configuration, punctate ornamentation; and antero- and postero-dorsal angles; from $C$. ( $\left.L i i_{0}.\right)$ sp. 3, by a smaller $1 / 1 / 1$ ratio and overall configuration.

Local ity: ${ }^{\mathrm{V}}$ Knocklofty Formation, Knocklofty.

\section{Cyzious (Lioestheria) sp. 3}

$$
\text { (P. 1, fig. 11) }
$$

Diagnosis: broadly ovate valve, truncated by a straight dorsal margin; umbo subtermina1; ornamentation punctate.

Measur ement: length $4.05 \mathrm{~mm}$.

Material: carbonized, flattened impression of a single left valve. UT 10, Slab

54664 .

Locality: Knocklofty Formation, Knocklofty .

Discussion: differs from $C$. (Lio.) $\mathrm{sp} .1$ in overall configuration and ornamentation.

Palaeolimnadia Raymond, 1946

The genus is divided into two subgenera to accommodate the natural groupings of specimens found in the Canning Basin and elsewhere. The two genera are defined as: Palaeolimnadia (Palaeolimnadia), with few growth bands, and $h / 1$ ratio of $0.82 \pm$, and Palaeolimnadia (Grandilmnadia) with few-to-numerous growth bands and h/l of $0.63 \pm$.

Palaeolimnadia (Palaeolimnadia) cf. wianamattensis Mitche11, 1927

$$
\text { (Pl. 1, fig. 6) }
$$

Diagnosis: ovate palaeolimnadid with large round umbo greater than fifty percent the total length of valve; with comparatively few growth bands.

Material: posterior third of left valve covered; median sector to ventral margin, crushed (UT 28, S1ab 88059).

Measurements: length $1.80 \mathrm{~mm}$; height $1.35 \mathrm{~mm} ; \mathrm{h} / 1=0.75 \pm$; length of umbo $\left(1_{\mathrm{u}}\right) 1.20$ $\mathrm{mm}$, height of umbo $\left(\mathrm{h}_{\mathrm{u}}\right) 1.05 \mathrm{~mm} ; \mathrm{h}_{\mathrm{u}} / \mathrm{l}_{\mathrm{u}}=0.87$.

Discussion: While incomplete preservation prevents species description, the large umbo and few growth bands suffice to place the genus and subgenus. The h/l ratio falls close to that for Palaeolimnadia (Palaeolimnadia) wianamattensis Mitchell, 1927 (fig. 

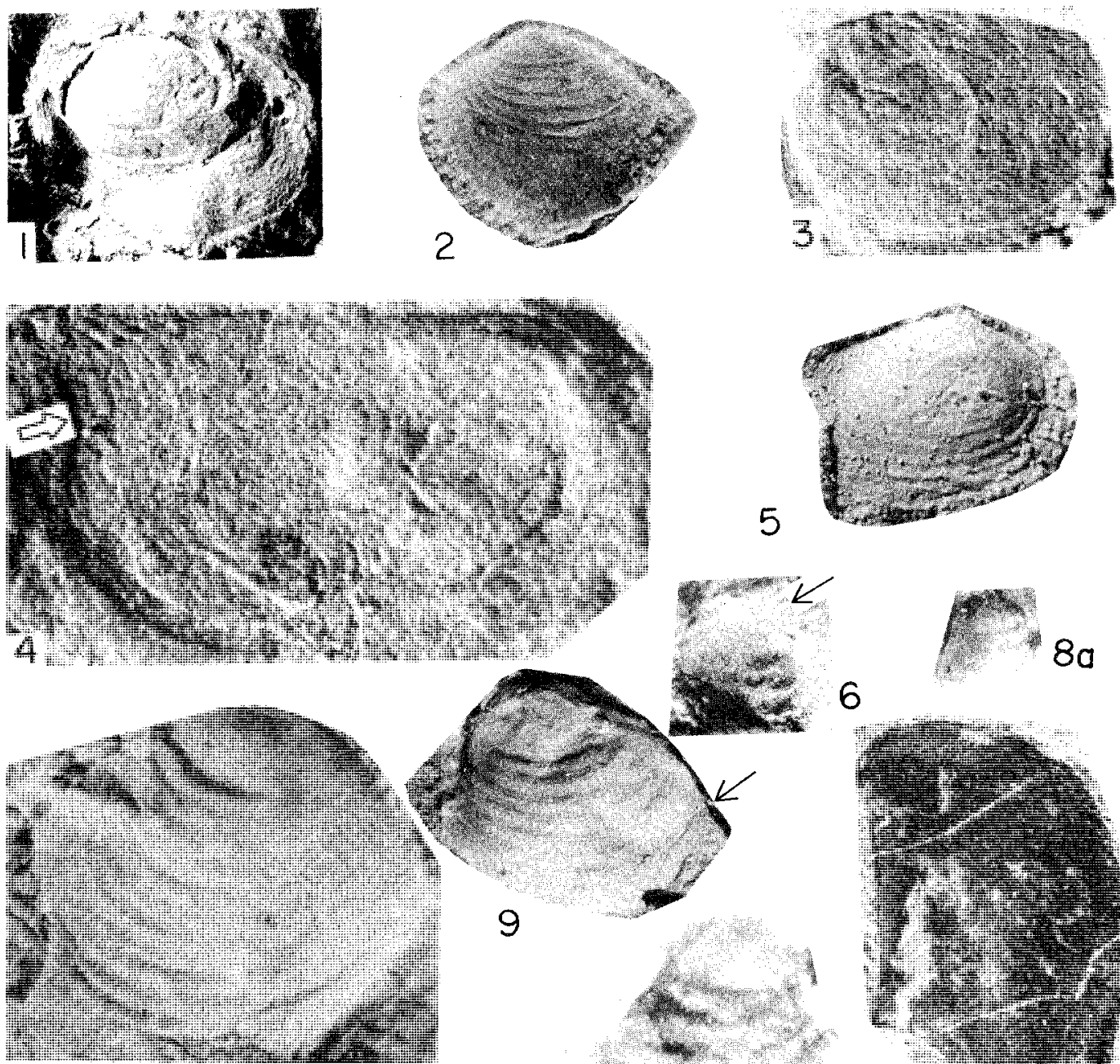

$7 b$
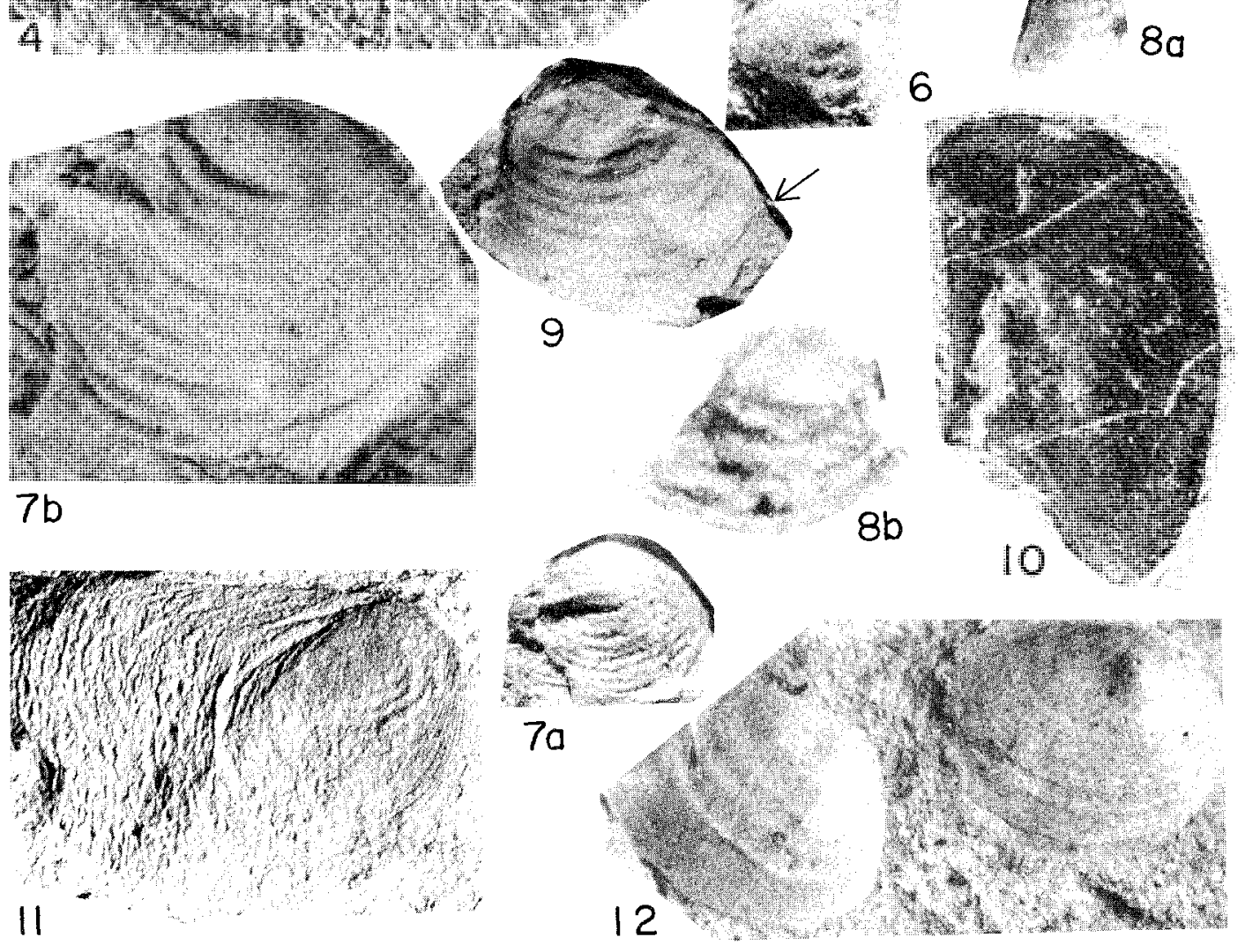
Pau1 Tasch

PLATE 1

Explanation of Figures

Fig. 1: Palaeolimnadia (Grandilimnadia) sp. 1. Knocklofty Formation, Cascades, UT-14, S1 ab 88059; left valve, height $2.55 \mathrm{~mm}$.

Fig. 2: Palaeolimnadia (Palaeolimnadia) poatinis n. sp. Holotype. Ross Sandstone, Poatina, UT-3, S1ab 55663; right valve, note elliptica1 umbo, length $2.10 \mathrm{~mm}$.

Fig. 3: Cyzicus (Lioestheria) sp. 2. Knocklofty Formation, Knocklofty, UT-11, S1ab 54664; a pair of carbonized valves; upper, left valve, length $4.05 \mathrm{~mm}$.

Fig. 4: Palaeolimnadopsis tasmanii n. sp. Holotype. Knocklofty Formation, Tinderbox Bay, UT-9, S1ab 54662; arrow points to posterior recurvature of 1 ast 4-5 growth bands, length $5.10 \mathrm{~mm}$.

Fig. 5; 12: Palaeolimnadia (Palaeolimnadia) banksia n. sp. 5, Holotype. Ross Sandstone, Poatina, UT-80, Slab 54665; right valve with 1 arge umbo and nine growth bands, length $2.70 \mathrm{~mm}$ : 12, Paratype. Ross Sandstone, Poatina, UT-6, 1, Slab 54665B; two right valves; one with apparent node or spine (an artifact of uneven crushing), 1 ength $2.40 \mathrm{~mm}$.

Fig. 6: Palaeolimadia (PaZaeolimnadia) cf wianamattensis Mitche11, 1927. Knock1ofty Formation, Cascades, UT-28, S1ab 88059; left valve, with umbo greater than 50 percent of valve length and few growth bands, arrow points to umbo, 1 ength $1.80 \mathrm{~mm}$.

Fig. 7: Palaeolimnadia (Palaeolimadia) sp. 1. Knocklofty Formation, Cascades, UT-40, Slab 88059. a, right valve, height $1.57 \mathrm{~mm}$; b, Same, X40.

Fig. 8: Palaeolimadia sp. Knocklofty Formation, 01d Beach, in conglomeratic 1ens in sandstone, TUT, 105; Subgenus undetermined due to fragmentary preservation, but note typical, large, palacolimnadid umbo; a, length of umbo $0.47 \mathrm{~mm}$; b, same, greatly enlarged to show configuration and siz $\overline{\mathrm{e}}$ of umbo.

Fig. 9: Palaeolimnadid right valve impression, bearing evidence of probable epibionts (worm borings) represented by white streaks; and negative of arthropod beaded fecal string (arrow); Knocklofty Formation, Crisp and Gunns Quarry, Knocklofty; TUT-105; 1ength $1.6 \mathrm{~mm}$.

Fig. 10: Probable malacostracan carbonized carapace valve (articulation to a left carapace valve in life inferred); Knocklofty Formation, Crisp and Gunn Quarry, Knocklofty; UT, S1ab 93983; length $7.50 \mathrm{~mm}$.

Fig. 11: Cyzicus (Lioestheria) sp. 3. Note broad ovate configuration. Knocklofty Formation, Knocklofty; UT-10, S1ab 54664; length $4.05 \mathrm{~mm}$. 


\section{Triassic Non-Marine Arthropoda}

8 only) but differs from it in being a rounded umbo as contrasted to the ovate umbo in Mitchell's species.

Locality: Knocklofty Formation, Cascades .

PaZaeolomnadia (Palaeolimnadia) banksia n. sp.

$$
\text { (P1. 1, figs. 5, 12) }
$$

Diagnosis: ovate to subovate, very convex valves with large umbo; nine or less growth bands.

Material: A porous sandstone slab contains an eccentrically ovate light gray shale chip (34 mm $\times 18 \mathrm{~mm}$ ) bearing $40+$ conchostracan valve impressions, including seven of the new species (Slab 54663B). Another slab with a light gray shale chip (Slab 54665) contains one complete specimen (UT 80), and one incomplete specimen (UT 81).

Measurements :

\begin{tabular}{|c|c|c|c|c|c|c|c|c|c|c|}
\hline Slab \# & Type & $\begin{array}{l}\text { Specimen } \\
\text { No. }\end{array}$ & $\begin{array}{c}\text { length } \\
\text { (mm) }\end{array}$ & $\begin{array}{c}\text { height } \\
\text { (mm) }\end{array}$ & $\mathrm{h} / 1$ & $l_{u}$ & $\mathrm{~h}_{\mathrm{u}}$ & $\mathrm{h}_{\mathrm{u}} / 1 \mathrm{u}$ & $G-B^{*}$ & a \\
\hline 54665 & Holotype & UT 80 & 2.70 & 2.10 & 0.77 & 1.20 & 0.75 & 0.62 & 9 & $35^{\circ}$ \\
\hline $54663 \mathrm{~B}$ & Paratype** & UT 6,1 & 2.40 & 1.95 & 0.81 & 1.08 & 0.58 & 0.53 & 6 & $30^{\circ}$ \\
\hline $54663 \mathrm{~B}$ & Paratype & UT 6,4 & 2.08 & 1.60 & 0.77 & 1.20 & 0.66 & 0.55 & 4 & $30^{\circ}$ \\
\hline
\end{tabular}

${ }^{*} \mathrm{G}-\mathrm{B}=$ growth bands

**Apparent spine is a pseudostructure due to uneven crushing of valve.

Name: The species name is for Mr. Max Banks, University of Tasmania. Locality: Ross Sandstone, Poatina.

Palaeolimnadia (Palaeolimnadia) poatinis n. sp.

(Pl . 1, fig. 2)

Diagnosis: subovate valve with comparatively large elliptical umbo and ten growth bands.

Material: impression of right va1ve, UT 3, slab 55663.

Measurements: 1 ength $2.70 \mathrm{~mm}$, height $2.10 \mathrm{~mm}, \mathrm{~h} / 1=0.77 ; 1$ ength of umbo $1.0 \mathrm{~mm}$, height of umbo $0.47 \mathrm{~mm}, h_{1} / 1=0.47$; antero-dorsal angle $45^{\circ}$; postero-dorsal angle $30^{\circ}$. Discussion: This species differs from $P$. (P.) banksia in larger antero-and posterodorsal angles, and smaller $h / 1$ ratio, while sharing the same $h / 1$ ratio. It differs from $P$. (P.) wianamattensis chiefly in umbonal ratio $h_{\mathrm{u}} / 1_{\mathrm{u}}$ being markedly smaller in the new species.

Locality: Ross Sandstone, Poatina.

Palaeolimnadia (Palaeolimnadia) sp. 1

$$
\text { (P1. 1, figs. 7a, 7b) }
$$

Diagnosis: very convex, sub-round palaeolimnadid with comparatively large umbo and 12 growth bands.

Materia1: right valve that is crushed in median sector, eroded along posterior and postero-dorsa1 margins. UT 40, slab 88059 .

Measurements: 1ength $1.95 \mathrm{~mm}$, height $1.57 \mathrm{~mm} ; \mathrm{h} / 1=0.80 ;$ length of umbo $0.37 \mathrm{~mm}$, height of umbo $0.53 \mathrm{~mm}$, antero-dorsal angle $30^{\circ}$.

Discussion: this species based on measured parameters is closest to $P$. ( $P$.) banksia, but poor preservation prevents a clearcut determination.

Locality: Knocklofty Formation, Cascades.

Palaeolimnadia (Grandizimnadia) sp. 1

(P1 . 1, fig. 1) 
Paul Tasch

Diagnosis: broadly ovate valve with large elliptical umbo situated closer to anterior end; straight dorsal margin that sharply arches posteriorly; variable growth band number to $17+$.

Material: specimens include one crushed left valve (UT 14) and a right valve with anterior and dorsal margins covered (UT 25). Slab 88059.

Measurements: Length $3.75 \mathrm{~mm}$, height $2.55 \mathrm{~mm} ; \mathrm{h} / 1=0.68 ; \mathrm{h}_{\mathrm{u}} / \mathrm{l}_{\mathrm{u}}=0.90$.

Locality: Knocklofty Formation, Cascades and Old Beach.

\section{Palaeolimnadopsis tasmanii n. sp.}

(P1. 1, fig. 4)

Diagnosis: oblong valves with gentle posterior recurvature visible on last 4-5 growth bands; postero-dorsal margin obscure; umbo subcentral, and situated below straight dorsal margin; last ten growth bands tightly spaced.

Material: a single specimen retaining distinctive features, eroded and crushed. UT 9 , slab 54662.

Measurements: Length $5.10 \mathrm{~mm}$, height $3.00 \mathrm{~mm} ; \mathrm{h} / 1=0.58 ; 1$ ength of dorsal margin $\left(1_{\mathrm{dm}}\right) 3.95 \mathrm{~mm} ; 1_{\mathrm{dm}} / 1=0.77$.

Discussion: Palaeolimnadopsids are known from the Carboniferous to the Cretaceous. They occur in the lower Triassic of Germany, the Kouznetsk Basin, and the Volga River (Vetlouga Stage). The Tasmanian species differs from P. brevis (Volga River) in configuration and antero-dorsal angle; from P. alberti (Germany and U.S.S.R.) in its oblong configuration and $h / 1$ ratio, although the ratio $l_{1} / 1$ corresponds to that of one of the U.S.S.R. specimens (Novojilov, 1955, p1. 1, flg. 11, Specimen No. 1322 (5). Furthermore the posterior recurvature of growth bands is much more pronounced in the Tasmanian species.

Locality: Knocklofty Formation, Tinderbox Bay .

\section{Class Malacostraca}

Subclass, Order, and Family Uncertain

$$
\text { (P1, 1, fig. 10) }
$$

Diagnosis: carapace valves subovate, feebly arched at midline, presumably separable at median hingeline; arcuate posterior notch; valves with marginal posterior ridge; slightly elevated with valve face raised above gentle slopes at hingeline and anterior margin, and a latera1, marginal, flat flange; faint growth bands about periphery of valves, and longitudinal markings on inner face of fragmentary valve; complete valve bears minute pustules.

Material: two carbonized valves, one complete, one fragmentary, eroded and the inner face exposed: two slabs, UT 93983.

Measurements: complete valve: length (anterior to posterior arc) $7.50 \mathrm{~mm}$; width $4.05 \mathrm{~mm}$; 1ength of posterior valve horn $2.55 \mathrm{~mm}$.

Discussion: The lack of definitive carapace structures of known malacostracan suborders (inferred median hingeline, the exception) disallows taxonomic placement of these fossil valves. The arcuate posterior notch, and rounded anterior, has many parallels among malacostracans. It should be observed that the two valves occur on separate slabs, and the carapace arrangement in life, is inferred.

Locality: Knocklofty Formation, Knocklofty (Crisp and Gunn Quarry, top of Arthur Street, Hobart).

\section{REFERENCES}

Cosgriff, J.W., 1974: Lower Triassic Temnospondyli of Tasmania. Geol. Soc. Amer. Special Paper 129.

Mitchel1, J., 1927: The Fossil Estheriae of Australia. Proc. Linn. Soc., N.S.W., $52,105-112$. 


\section{Triassic Non-Marine Arthropoda}

Novojilov, N., 1955: Recueil d'Articles sur les phyllopods Conchostraces: Ann. Serv. D'Information Geol. du B.R.G.G.M (Jan. 1958) No. 26, 95-103.

Smith, E.M. and Williams, E., 1965: GEOLOGICAL EXCURSIONS FOR ANZAAS 38TH CONGRESS. Tas, Dept. Mines, (Poatina, pp. 39-40).

Spry,A.H. and Banks, M.R., (Editors), 1962: THE GEOLOGY OF TASMANIA. J. geol. Soc. Aust., $9(2), 107-362$.

Tasch, P., Sastry, M.V.A., Shah, S.C., Rao, B.R.J., Rao, C.N. and Ghosh, S.C., 1975: Estheriids of the Indian Gondwanas. Significance for Continental Fit. in K.S.W. Campbel1 (Ed.) GONDWANA GEOLOGY. A.N.U. Press, 443-452.

Tripathi, C. and Satsangi, P.V., 1963: Lystrosaums Fauna of the Panchet series of the Raniganj coalfield. Mem. Geol. Surv. India. G.S.I. New Series, 37, 51 pp., pls. $1-13$. 